International Journal of Engineering \& Technology, $7(4.34)(2018) 277-280$
International Journal of Engineering \& Technology
SPC
Website: www.sciencepubco.com/index.php/IJET
Research $p a$

\title{
Business Ethics Perception as Moderating Variable on the Influence of Management Accounting System to Managerial Performance (Study at PT Bank Mandiri (Persero), Tbk.)
}

\author{
Veronica Christina*, Mohd Haizam Mohd Saudi, Silviana, Nina Nurani, Obsatar Sinaga \\ Widyatama University, Bandung, Indonesia \\ *Corresponding author E-mail: veronica.christina@widyatama.ac.id
}

\begin{abstract}
This study aims to determine the effect of management accounting systems on managerial performance with business ethics perception as a moderating variable in PT Bank Mandiri (Persero) Tbk. The populations in this study were top, middle and lower managers who were responsible for the performance of ten branch offices of PT Bank Mandiri (Persero) Tbk in the city of Bandung and the population was 80 people. The results showed that business ethics perception was able to moderate the influence of management accounting systems on managerial performance.
\end{abstract}

Keywords: management accounting system; managerial performance; perception business ethics.

\section{Introduction}

Research in the field of management accounting systems with managerial performance has been done a lot, but the results of the research show not conclusive. Research conducted by [3, 7-8, 13] succeeded in proving that management accounting systems have a positive effect on managerial performance. However, research conducted by [21] has not succeeded in proving that managerial performance was influenced by management accounting systems. Today's business competition requires managers to carry out their responsibilities well, and even not only good, but must be accompanied by ethical behavior. Ethics is a guideline for humans to take appropriate attitudes and actions in carrying out this life. According to [16], every business implementation must align its business processes with business ethics that have been agreed in general in that environment. This is in line with the opinion of [22] saying that ethic business is not a corporate code of ethics, but must be applied in line with the corporate philosophy.

Business ethics is a teaching to distinguish which is wrong and what is right so that it can be used as a basis for consideration for each company leader when making decisions. Someone who makes a decision will use the information available. If someone is able to perceive business ethics properly and correctly, it will be able to choose and use relevant information in making decisions so that their performance is good. This is in accordance with what was said by [2] that the success of an organization reflects employee confidence that can direct workers to develop transparency, integrity, organizational reputation and good work processes, all of which are caused by the role of business ethics.

\section{Theoretical Framework and Hypothesis Development}

\subsection{Management Accounting System}

The function of the management accounting system is to provide a way to communicate the objectives to all managers in the organization, providing feedback that allows a manager to monitor the daily operations of the inside of the company under his responsibility [19]. Management accounting systems can be designed to provide more sophisticated information and not only help make decisions within the department but also help coordination between functional departments [4].

Management accounting systems based on management perceptions as the basis for decision making have characteristics such as broad scope, timeliness, aggregation and integration. broad scope is information that has a wide and complete scope, which usually includes economic aspects and non-economic aspects, timelines that are conceptualized have two dimensions namely reporting frequency and speed of making reports, aggregation is more concise information but still covers important things so as not to reduce the value of information itself, integration is an information characteristic that reflects the coordination between one segment and another [6].

Information plays a role in improving managerial ability to understand the state of the surrounding environment and identify relevant activities [15]. According to [8], the achievement of organizational goals will require management accounting information as a tool to plan budgets and as feedback to improve the performance of business entities, especially managerial. The description can be summarized in the H1 hypothesis: Management accounting systems affect managerial performance 


\subsection{Business Ethics Perception}

Business ethics in companies have a very important role namely that companies have the ability to create high value-creation, a solid foundation for forming a strong and highly competitive company [11]. "Ethics is a conception of right and wrong conduct. It tells us whether our behavior is moral or immoral and deals with fundamental human relationships". Business ethics is the application of general ethics to business behavior. As [17] said, business ethics can be said to study moral (ethics) systematically related to business, institutions or practices and beliefs of an industry. Business managers and employees need a set of decision guidelines that will shape their thinking when on-the-job ethics issues occur. These guidelines should help them: Identify and analyze the nature of an ethical problem, and decide which course of action is likely to produce an ethical result [10].

Some of the reasons put forward why a business should be done ethically are: to meet the demands of business stakeholders, to enhance business performance, to comply with legal requirements, to prevent harm and to promote personal morality.

Some studies have found that ethic business is able to improve performance in [2] found that business ethics has an improving quality of job performance role, in [1] research found that business ethics influenced growth, research conducted by [10] at the Bank also found that business ethics affects performance, so hypothesis 2 can be stated, H2: Business ethics influences management performance

\subsection{Managerial Performance}

Managerial performance is a measure of the effectiveness and efficiency of managers in carrying out their work to achieve organizational goals. In [18] more specifically explained that managerial performance is the performance of managers in managerial activities which include planning, investigating, coordinating, evaluating, supervising, staffing, negotiating, and representing or representing. The nature of employee performance is less abstract and complex than the managerial performance, it is making the manager's performance appraisal should be done by the manager himself.

A management accounting system that is able to provide information relevant to management will improve managerial performance. The contingency approach to the management accounting system is based on the general premise that there is no universal management accounting system that is always appropriate to be applied to all organizations in every situation, but management accounting systems depend on contextual factors in the organization [20]. The main proposition of contingency theory is that contingency theory assesses the company's performance will depend on the compatibility between the contextual factors of an organization [5]. One contextual factor that needs to be considered in the contingency approach is organizational behavior. An interactionist perspective states that individuals and situations interact continuously to determine individual behavior or as a useful perspective to help better understand behavior in organizational situations. In this study, the business ethics perception as an individual and management accounting system as a situation that interacts with each other. When individuals enter an organization, their behavior and actions form the organization in various ways, so that the organization itself shapes the behavior and actions of each individual that is part of it which will ultimately affect performance [14]. The description can be formulated in a H3 hypothesis: Business ethic perception is able to moderate the influence of management accounting systems on managerial performance.

\section{Methodology}

The objects chosen in this study were top, middle and lower managers in ten branch offices of PT Bank Mandiri (Persero) Tbk in the City of Bandung. The number of managers as many as 80 people who are the population, in this study all will be sent a questionnaire. The number of returned questionnaires is considered as a sample. This research is an explanatory research [6], instrument used to measure Management Accounting System variable that consisting of 19 items with an itemized attitudinal scale. Managerial Performance variables are measured using instrument developed by [18] consisting of 9 questions, which are itemized attitudinal scales Variables perception business ethics are measured using instruments based on [9] consisting of 15 questions that use the numerical scale. All variables are in interval. Data will be analyzed using moderated regression analysis.

\section{Results and Analysis}

A total of 80 questionnaires were received and deserved to be processed. Validity test of the items of the research questionnaire was done using the Pearson Product Moment Correlation Test, showing all the questions items are valid with $\mathrm{R}$ count above the critical point of 0.30 . Reliability testing is done using the Cronbach's Alpha method. All variables have a coefficient above the critical point 0.7 , which means that the three variable instruments are reliable. The classic assumption test shows that the data for the three variables are normally distributed, there is no multicollinearity or heteroscedasticity. Data processing results can be seen in the following tables.

Table 1: Coefficient Determination of the Effect of Management Accounting Systems on Managerial Performance

\begin{tabular}{|c|c|c|c|c|}
\multicolumn{5}{|c|}{ Model Summary } \\
Model & $\mathrm{R}$ & R Square & $\begin{array}{c}\text { Adjusted R } \\
\text { Square }\end{array}$ & $\begin{array}{c}\text { Std. Error of } \\
\text { the Estimate }\end{array}$ \\
\hline 1 &, $388^{\mathrm{a}}$ &, 150 &, 140 & 4,88197 \\
\hline
\end{tabular}

a. Predictors: (Constant), Management Accounting System (X)

Table 2: Estimation Results of Regression Equations Effect of Management Accounting Systems on Managerial Performance

Coefficientsa

\begin{tabular}{|c|c|c|c|c|c|c|}
\hline \multirow{2}{*}{\multicolumn{2}{|c|}{ Model }} & \multicolumn{2}{|c|}{$\begin{array}{c}\text { Unstandardized } \\
\text { Coefficients }\end{array}$} & \multirow{2}{*}{$\begin{array}{c}\begin{array}{c}\text { Standardized } \\
\text { Coefficients }\end{array} \\
\text { Beta } \\
\end{array}$} & \multirow[b]{2}{*}{$\mathrm{T}$} & \multirow[b]{2}{*}{ Sig. } \\
\hline & & $\mathrm{B}$ & $\begin{array}{l}\text { Std. } \\
\text { Error }\end{array}$ & & & \\
\hline \multirow[t]{2}{*}{1} & (Constant) & 17,317 & 2,815 & & 6,151 &, 000 \\
\hline & $\begin{array}{c}\text { Sistem } \\
\text { Akuntansi } \\
\text { Manajemen } \\
(\mathrm{X})\end{array}$ & , 177 & ,048 & ,388 & 3,717 & ,000 \\
\hline
\end{tabular}

a. Dependent Variable: Kinerja Manajerial (Y)

Table 1 and 2 show that management accounting system effect managerial performance by $14 \%$ and can explain variation of managerial performance about $38.8 \%$.

Table 3: Coefficient Determination of the Effect of Management Accounting System and Perception Business Ethics on Managerial Performance

\begin{tabular}{|c|c|c|c|c|} 
Model & R & R Square & $\begin{array}{c}\text { Adjusted R } \\
\text { Square }\end{array}$ & $\begin{array}{c}\text { Std. Error of the } \\
\text { Estimate }\end{array}$ \\
\hline 1 &, $435^{\mathrm{a}}$ &, 190 &, 168 & 4,79929 \\
\hline
\end{tabular}

Table 4: Estimation Results of Regression Equations Effect of Management Accounting Systems and Perception Business Ethics on Managerial Performance

\begin{tabular}{|c|c|c|c|c|c|c|}
\hline Model & & $\begin{array}{l}\text { Sum of } \\
\text { Squares }\end{array}$ & $d$ & Mean Square & $F$ & $\mathrm{Sig}$ \\
\hline \multirow[t]{3}{*}{1} & Regression & 414,701 & 2 & 207,350 & 9,002 & $.000^{b}$ \\
\hline & Residual & 1773,555 & 77 & 23,033 & & \\
\hline & Total & 2188256 & 79 & & & \\
\hline
\end{tabular}

a. DependentVariable: Kineria Manajerial (M)

b. Predictors. (Constant), Persepsi Etika Bisnis (Z), Sistem Akurtansi Manajemen (Q) 
Table 5: Partially Effect of Management Accounting System and Perception Business Ethics on Managerial Performance

$$
\text { Coefticients" }
$$

\begin{tabular}{|c|c|c|c|c|c|c|}
\hline & & \multicolumn{2}{|c|}{$\begin{array}{c}\text { Unstandardized } \\
\text { Coefficients }\end{array}$} & $\begin{array}{l}\text { Standardiced } \\
\text { Coeticients }\end{array}$ & \multirow[b]{2}{*}{$t$} & \multirow[b]{2}{*}{$\operatorname{sig}$} \\
\hline \multicolumn{2}{|c|}{ Nodel } & B & Std. Erroe & Beta & & \\
\hline \multirow[t]{3}{*}{1} & (Constant) & 21.778 & 3,609 & & 6,035 & .000 \\
\hline & $\begin{array}{l}\text { Sistem Akuntarisi } \\
\text { Manajemen }(10\end{array}$ & .164 & .047 & .359 & 3,465 & .001 \\
\hline & $\begin{array}{l}\text { Persepsi Etika } \\
\text { Bisnis (Z) }\end{array}$ & -101 & .052 &,- 200 & $-1,926$ & .058 \\
\hline
\end{tabular}

a. Dependent Vatiable: Kinerja Manajerial $(m$

Table 3, 4, and 5 show that management accounting system and perception business ethics effect managerial performance by $16.8 \%$, and variation of two independent variables can explain the variation of managerial performance, but partially perception business ethics not significantly influence managerial performance.

Table 6: Moderated Regression Analysis

Model Summary

\begin{tabular}{|l|l|r|r|r|}
\hline Model & R & R Square & $\begin{array}{c}\text { Adjusted R } \\
\text { Square }\end{array}$ & $\begin{array}{c}\text { Std. Error of } \\
\text { the Estimate }\end{array}$ \\
\hline 1 &, $574^{\mathrm{a}}$ &, 330 &, 303 & 4,39286 \\
\hline
\end{tabular}

a. Predictors: (Constant), XZ, Sistem Akuntansi Manajemen (X), Persepsi Etika Bisnis (Z)

\begin{tabular}{|c|c|c|c|c|c|c|}
\hline \multicolumn{7}{|c|}{$\begin{array}{c}\text { Table 7: ANOVA } \\
\text { anovn" }\end{array}$} \\
\hline Modet & & $\begin{array}{l}\text { Sumbo } \\
\text { Squares }\end{array}$ & a & Mean Square & $\mathrm{F}$ & 80 \\
\hline \multirow{3}{*}{1} & Regrossion & 721,666 & 3 & 240,555 & 12,466 & $.000^{6}$ \\
\hline & Residual & 1466590 & 76 & 19,297 & & \\
\hline & Total & 2188.256 & 79 & & & \\
\hline
\end{tabular}

a. Dependerd Variable: Konerja Manajerial (M)

b. Freactors (Constant), $X Z$, sistem Akuntansi Manajemen $\infty$, Persepsi Etka Bisnis (2)

Table 8: Coefficient Correlation Coefficients ${ }^{a}$

\begin{tabular}{|c|c|c|c|c|c|c|}
\hline & & \multicolumn{2}{|c|}{$\begin{array}{l}\text { Unstandardized } \\
\text { Coefficients }\end{array}$} & \multirow{2}{*}{$\begin{array}{c}\begin{array}{c}\text { Standardized } \\
\text { Coeficients }\end{array} \\
\text { Beta } \\
\end{array}$} & \multirow[b]{2}{*}{ t } & \multirow[b]{2}{*}{ Sig. } \\
\hline \multicolumn{2}{|c|}{ Model } & $B$ & Std. Error & & & \\
\hline 1 & (Constant) & 21,006 & 3,309 & & 6,349 & .000 \\
\hline & $\begin{array}{l}\text { Sistem Akuntansi } \\
\text { Manajemen }(\infty)\end{array}$ & .152 & .043 & .334 & 3,513 & .001 \\
\hline & $\begin{array}{l}\text { Persepsi Eoka } \\
\text { Bisnis (Z) }\end{array}$ &,- 069 & .049 &,- 136 & $-1,418$ & .160 \\
\hline & $x z$ & $-1,857$ & .466 & -381 & $-3,988$ & .000 \\
\hline
\end{tabular}

a. Dependent Wariable: Kinerja Manajerial (M)

Tables 6,7 , and 8 show that business ethics perceptions can moderate the effect of management accounting systems on managerial performance, it means that the perception of business ethics can weaken the influence of management accounting systems on managerial performance.

\section{Discussion}

This study shows the business ethics perception has a negative effect on the relationship between management accounting systems and managerial performance, meaning business ethics perception is a moderating variable that weakens the relationship between management accounting systems and managerial performance. The results of this study contradict the theory and results of previous studies such as found by $[1-2,10]$. It can be explained that in Indonesia for more than two decades the level of corruption has a high tendency, so doing business ethically will reduce performance. The Indonesian government is currently actively implementing a mental revolution program. This program is a strate- gy for human development and culture to change national character from negative mental character to positive character.

The results of this study also contradict to the results of research conducted by [12], who found that the application of business ethics affects customer satisfaction. This research was conducted at a restaurant in Indonesia. The study also found that fairness and honesty did not affect customer satisfaction.

\section{Conclusion}

The results show that:

1. The management accounting system influences managerial performance. This means that variations in the value of management accounting systems are able to explain variations in managerial performance values.

2. The business ethics perception is a pure moderator which weakens the relationship between management accounting systems and managerial performance. This means that the better the perception of manager about business ethics the weaker the influence of the management accounting system on managerial performance.

The advice that can be given is managers should be given upgrading on the importance of understanding business ethics, so that they are able to carry out their work in accordance with applicable ethics, even if education about ethics can be given since the age of children

\section{References}

[1] Enofe, A.O., O.L. Ogbeide and O.M. Julius. 2015. Business Ethics and Corporate Growth. Business Ethics, 7(15), 139-148

[2] Al Mahjob, J.A.A. 2018. The Role of Business Ethics in Improving the Quality of Job Performance. Journal of Entrepreneurship and Organization Management, 7(1), 1-4.

[3] Aida, A.M. and Gudono. 2011. Pengaruh Ketidakpastian Lingkungan Dan Desentralisasi Terhadap Karakteristik Informasi Sistem Akuntansi Manajemen. Jurnal Riset Akuntanasi Indonesia, 4(1).

[4] Bouwens, J. and M.A. Abernethy. 2000. The Consequences of Customization of Management Accounting System Design. Accounting, Organization and Society, 24(2), 221-241.

[5] Cadez, S. and C. Guilding. 2008. An Exploratory Investigation of an Integrated Contingency Model of Strategic Management Accounting. Accounting, Organizations and Society, 33, 836-863.

[6] Chenhall, R.H. and Morris D. 1986. The Impact of Structure, Environment, and Interdependence on The Perceived Usefulness of Management Accounting System. The Accounting Review, 6(1), 16-35.

[7] Chong, V.K. and Chong, K.M. 1996. Management Accounting System, Task Uncertainty and Managerial Performance: A Research Note. Accounting, Organizations and Society, 21(25), 415-421.

[8] Christina, V. 2010. Pengaruh Individual Differences terhadap Sistem Informasi Akuntansi Manajemen dan Dampaknya Bagi Kinerja Manajerial. Universitas Padjadjaran.

[9] Deshpande, S.P., Jacob, J. and Vasily, V.M. 2000. Perception of Proper Ethical Conducts of Male and Female Russian Managers. Journal of Business Ethics, 24, 179-183.

[10] Ebitu, E.T. and Beredugo, S.B. 2015. Business Ethics and Performance of Service Firm in Calabar Cross River State Nigeria. European Journal of Hospitality and Tourism Research, 3(2), 28-38.

[11] Embse, Von der \& Wagley, R.A. (1988). Managerial Ethics Hard Decisions on Soft Criteria. SAM Advanced Management Journal, 53(1), 1-6.

[12] Fauzan and Ida, N. 2014. Pengaruh Penerapan Etika Bisnis terhadap Kepuasa Pelanggan Warung Bebek H Slamet di kota Malang. Jurnal Ekonomi Modernisasi, 10(1), 38-55.

[13] Gul, F.A. and Chia Y.M. 1994. The Effects of Management Accounting System Perceived environmental uncertainty and decentralization on Managerial Performance: A test of a Three Way Interaction. Accounting Organization and Society, 19(4-5), 413426.

[14] Moorhead, G. and Ricky, W.G. 2013. Organizational Behavior: Managing People and Orgnizations. Salemba Empat. 
[15] Nazaruddin, I. 1998. Pengaruh Karakteristik Sistem Informasi Akuntansi terhadap Kinerja Manajerial. Jurnal Akuntansi Keuangan, 7(2), 100-112.

[16] Hill, C.W., Jones, G.R. and Schilling, M.A. 2014. Strategic Management Theory: An Integrated Approach. Cengage Learning.

[17] John, D. 1989. Key issues in Business Ethics. Academic Press.

[18] Mahoney, T.A., Jerdee, T.H. and Carrol, S.J. 1963. Development of Managerial Performance: Performance A Research Approach. South-Western Publishing Company.

[19] Norgaard, C.T. 1985. Management Accounting. Prentice Hall.

[20] Otley, D.T. 1980. The Contingency Theory of Management Accounting: Achievement and Prognosis. Accounting Organization and Society, 5, 413-428.

[21] Rustiana. 2002. Pengaruh Sistem Akuntansi Manajemen, Desentralisasi dan PEU terhadap Kinerja manajerial: Three Way Interaction. Jurnal Riset Ekonomi dan Manajemen, 2(2), 70-88.

[22] Yamaji K. 1997. A Global Ethics perspective in Business. Business Ethics Quarterly, 7(3), 55-70. 